\title{
"I Just Don't Have the Capability": Examining the Impact of Declining Arts Education on Teacher Beliefs
}

\author{
Susanne Garvis, University of Queensland, Queensland, Australia
}

\begin{abstract}
Arts education is an essential component of a comprehensive education, requiring highly skilled teachers to achieve quality arts education (Andrews, 2004). Teachers gain such skills in teacher education, to enhance their confidence and capability in teaching the arts. Without these necessary skills however, they may develop a lack of confidence, motivation and knowledge (Henessy, Rolfe, \& Chedoy, 2001; Russell-Bowie, 2004). Greater recognition of experiences in arts education in teacher training is necessary to shed light on the current problem of instigation of the arts in schools. This paper provides insights into a research project that attempts to contribute towards filling this void, in order to improve teachers' effectiveness in the arts domain. It examines beginning teachers' experiences during their arts teacher education and the impact of these experiences on their current engagement with arts education. Results suggest that with this group of beginning teachers, limited or negative exposure to arts education during teacher training may reduce the likelihood that a beginning teacher will engage with the arts as part of their teaching practice.
\end{abstract}

Keywords: Arts Education, Teacher Beliefs, Teacher Training

\section{Introduction}

$\mathrm{A}$

RTS EDUCATION IS an essential component of a comprehensive education, requiring highly skilled teachers to achieve quality arts education (Andrews, 2004). Teachers gain such skills in teacher education, to enhance their confidence and capability in teaching the arts. They must understand the instructional purpose, feel confident in their skills and recognise the benefits to effectively teach the arts in their classrooms (Hord, Rutherford, Hurling-Austin \& Hall, 1998; Upitis \& Smithrim, 2003). As Darling-Hammond (2000) suggests, the quality of teaching that occurs in schools is directly attributed to the quality of preparation within teacher education.

If these skills are not developed during teacher training, it can lead to weak teacher selfefficacy beliefs towards arts education. Moreover, without supportive teacher education, generalist teachers will develop a lack of confidence, motivation and knowledge towards the arts (Henessy, Rolfe, \& Chedoy, 2001; Russell-Bowie, 2004). These factors may contribute to even lower teacher self-efficacy towards arts education.

In 2005, a National Review of Australian School Music (National Review, 2005) raised a number of questions in relation to the training generalist teachers receive in music and the arts in teacher training. The Review highlighted a decline in the number of hours given for generalist primary pre-service education courses (National Review, 2005) suggesting preservice teachers did not have adequate time to enhance their teaching skills. Subsequently, the Review recommended the need to enhance and transform courses for generalist classroom teachers to ensure that there is dedicated time for music and that pre-service teachers develop 
and demonstrate knowledge, understanding and skills in their own music making as well as teaching music.

This study provides an update of the current situation of arts education in teacher education. In late 2008, I collected 201 questionnaires from beginning teachers throughout Queensland Australia to explore current perceptions of beginning teachers on their teacher education in the arts. I also wanted to see if courses had improved since the National Review's recommendations.

\section{Teacher Self-Efficacy and Teaching the Arts}

Teacher self-efficacy beliefs towards the arts will determine the level to which the teacher will teach arts education in the classroom. Teacher self-efficacy is developed through the interaction between an individual's judgment of their teaching ability to perform a task and their perception the actions required to perform that task successfully. This type of interaction is the self-efficacy process defined by Bandura (1986). Teacher self-efficacy is responsible for the motivation and the actual amount of effort that an individual will bring to the task as they access their ability to perform the teaching task successfully.

Bandura (1997) suggested that the higher the sense of self-efficacy, the greater the perseverance and the higher the chance that the pursued activity would be performed successfully. Teachers with higher self-efficacy were likely to put more effort into planning and teaching, to have higher expectations of students and to find strategies that would help students learn (Bandura, 1997). Beliefs appeared to be influenced by confidence (Tosun, 2000), level of content knowledge for a subject (Borko \& Putnam 1995; Muijs \& Reynolds, 2001) and support structures available (Ashton \& Webb, 1987).

Teacher self-efficacy research within the area of music and the arts show similar findings. Previous research by Temmerman (1997) and Bartel and Cameron (2002) which showed that a perceived lack of competency to teach the specific knowledge and skills required in music was a significant internal factor affecting teachers' perceptions of their musical abilities. Kane (2008) has also explored generalist teacher's personal background with music on their competence. In a study of New South Wales generalist pre-service teachers, she found that, although many had studied music and played instruments at one time, they confessed they were no longer musically active and had forgotten much of what they had learned.

In an international comparison of pre-service teachers' perceptions for teaching arts education in primary schools across Australia (New South Wales), Nambia, South Africa, United States of America (Illinois) and Ireland, results highlighted further short falls in arts education (Russell-Bowie, 2004). Results suggested a universal trend of teachers' lack of knowledge and personal arts experiences significant to all five countries. Music education appears to be affected the greatest by these problems, followed by drama and dance education (RussellBowie, 2004). Moreover, teachers perceived beliefs, attitudes and self-perceptions can be seen to have a direct influence on how much and how well particular subjects or activities are pursued, by teachers (Guskey, 1988). 


\section{Focus of Study}

This study focuses on the perceptions of beginning generalist teachers on their teacher education in the arts and the impact of these experiences on their current engagement with arts education. In particular, the study focused on:

1. What were the positive effects of teacher education on current beginning teacher arts practice?

2. What were the negative effects of teacher education on current beginning teacher arts practice?

\section{Method}

This study gathered data from a questionnaire sent to beginning generalist teachers throughout Queensland, Australia. These teachers were still within the first three years of their teaching career since graduating from a teacher education institution. Beginning teachers taught in the middle years of schooling (year 4-9) in private and public schools. In total 201, usable questionnaires were returned after advertising for research participants through professional organisation, at schools at beginning teacher conferences.

Experiences during pre-service teacher education made up one section of the questionnaire. In an open question, teachers were asked to write the positive and negative experiences they may have had during their teaching training. The question was designed to capture teacher education experience.

Results were analysed using content analysis to show key themes that were common across beginning teacher's perceived experiences in teacher education. Content analysis is "a research technique for making replicable and valid inferences from texts to the context of their use (Krippendorf, 2004, p.18). Results have been discussed below.

\section{Results}

$74 \%$ of beginning teachers described negative experiences with arts during their teacher education courses. Results are presented in graph 1 . Beginning teachers spoke of the needs for application of their arts courses to a teaching context, problems with lecturers/ tutors, limited exposure at university to the range of arts subjects, competing subject interests with Maths and English, problems with assessment and general pressure. 


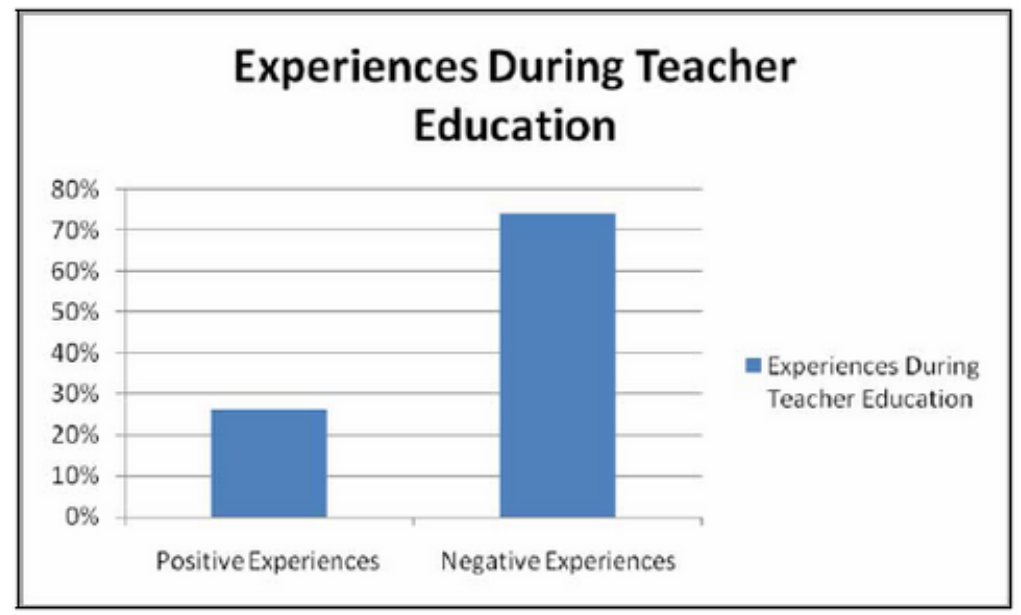

Graph 1: Experiences During Teacher Education

Beginning teachers who spoke of arts courses needing more application to the teaching context with arts courses being too theorised. Some beginning teachers also felt that what they had learned in arts courses did not improve their skills or relate to the real world. Beginning teachers called for arts courses to be made relevant and contextualised:

Arts education courses at university were very airy fairy. Due to the fact that they didn't provide any hands on experience. Theory is good in a university situation, but in the real world all that theory goes out the door the minute you walk into a classroom...MAKE IT RELEVANT TODAY! NOT YESTERDAY (Beginning Teacher, 64).

I studied externally so I learnt everything from texts. No observations (Beginning Teacher, 82).

I felt the uni arts class was a waste of time. I did not learn how to teach any form of the arts comprehensively (Beginning Teacher, 132).

I undertook one unit at university "intro to literature and drama". I didn't enjoy this unit at all. We seemed to learn little theory or understanding of components of theatre. Much of the contact was spent doing 'embarrassing' drama activities, in which I always felt uncomfortable. I remember feeling very frustrated at having to pay for a course that had me "galloping around like a horse". We were also given numerous contact hours to put together our own skit-rather than learning how to by our lecturer. (Beginning Teacher, 58).

Beginning teachers also talked about having lecturers and tutors who were too critical, unsupportive and unequitable in their teaching and learning of the arts:

We had a lecturer that was a bit over the top in terms of her criticism of the arts pieces that we had to do for assessment (Beginning Teacher, 6).

As it was the first year my degree was run I felt some of the lecturers made excuses for disorganisation in my course. Some of the arts courses were changed after our year as 
they did not meet expectations of the uni[versity] or the students (Beginning Teacher, 95)

Lecture were not very interesting and/or incomprehensible (Beginning Teacher, 27).

Beginning teachers also spoke of the low valuing of the arts within teacher education programmes. They felt the university placed greater emphasis on maths and English:

General education lecturers only provided a 'duh' kind of common sense outlook and overview of schooling life for the teacher. Too much focus was placed on maths and English and middle years and not enough focus placed on the importance of arts education (Beginning Teacher, 12).

$26 \%$ of beginning teachers did provide positive comments towards their arts education course in teacher education. These positive experiences were based around some arts courses being seen as relevant to teaching, peer interaction and assessment:

I was confident that I was going to have an 'artsy' classroom where all forms of meaningful arts experiences were implemented (Beginning Teacher, 114).

I enjoyed working with my peers at uni[versity] when completing visual art, music and drama activities (Beginning Teacher, 14).

My best learning experiences in this course were tutorial based whereby each group would get to teach the rest of the group a lesson in the arts (Beginning Teacher, 24).

Overall, the majority of beginning teachers did not consider they had adequate teacher training and considered this a major deterrent to teach the arts.

\section{Final Comments}

The above results provide an interesting starting point for analysis in the investigation of the perceptions of beginning teachers on their pre-service teacher education. It appears that the majority of beginning teachers did not have positive experience with arts teacher training because of problems within course organisation, structure and content. Without positive experiences to build knowledge, confidence and skills within the arts, beginning teachers may feel they have little capability when teaching music and the arts. Long term, these experiences may contribute to lower teacher self-efficacy for the arts, adding to the current problem of arts teaching within schools. These results confirm the findings from the 2005 National Review of School Music Education, suggesting few changes have been made to teacher education in the arts since this report.

Current practices in arts education courses within teacher education must be reviewed if teachers are expected to learn skills that they can use in the classroom. These arts courses must be relevant to the needs of pre-service teachers, enabling them to develop suitable knowledge and skills to teach the arts within the classrooms. Lecturers and tutors must model 'good arts practice' for students throughout all elements of the course including teaching, assessment and reflection. They must draw upon the prior knowledge of the preservice teacher, extending their knowledge and skills to be capable of teaching arts within the classroom. 
Of interest, $26 \%$ of beginning teachers mentioned positive experiences towards their arts training. They spoke of enjoying the interaction with peers and being able to practice teaching arts activities to one another. This suggests that some arts courses may be successful in being relevant to the needs of the generalist pre-service teacher. Both of these techniques are important for the development of positive teacher self-efficacy as they provide positive emotional arousal and allow students to benefits from developing collaborative teams. Accordingly, peers can also provide verbal support for the pre-service teacher as they gain mastery experience through practicing teaching the arts activity. Through peer interaction, modelling is also encouraged that allows students to model suitable arts techniques and skills to one another so they increase their knowledge and skills.

This paper reports results that raise some interesting question and starting points for further investigation in arts education. Particular interest will relate to reforming arts training in generalist teacher education programmes, to try and provide more positive experiences that can help build and support beginning teacher self-efficacy for the arts. It will be interesting to see also, if, over time, if positive experiences are acted upon, the students' levels of teacher self-efficacy for the arts. Would teachers subsequently feel more competent to teach the arts in the classrooms? Would teachers feel confident to engage their students with arts activities? If so, such knowledge would enable teacher training institutions to structure arts courses to more effectively enhance teachers' arts learning and instructional expertise in the arts. Pre-service teachers would be able to learn valuable knowledge and skills that they could later use when teaching within their generalist classrooms. It is therefore important that such research is conducted as teachers are expected to teach the arts within their classroom.

\section{References}

Andrews, B.W. (2004). Curriculum Renewal Through Policy Development in Arts Education. Research Studies in Music Education, 23, 76-93.

Ashton, P.T., \& Webb, R.B. (1986). Making a difference: Teachers' sense of efficacy and student achievement. New York: Longman.

Bandura, A. (1986). Social foundations of thought and action: A social cognitive theory. Englewood Cliffs, NJ: Prentice Hall.

Bandura, A. (1997). Self-efficacy: The exercise of control. New York: Freeman.

Borko, H., \& Putnam, R.T. (1995). Expanding a teacher's knowledge base: A cognitive psychological perspective on professional development. In T.R. Guskey \& M. Huberman (Eds.). Professional development in education: new paradigms and practices (pp. 35-65). New York: Teachers College Press.

Darling-Hammond, L. (Ed.) (2000b). Studies of Excellence in Teacher Education. Washington, D.C.: American Association of Colleges for Teacher Education and New York: National Commission on Teaching and America's Future.

Guskey, T. R. (1988). Teacher efficacy, self-concept, and attitudes toward the implementation of instructional innovation. Teaching and Teacher Education, 4, 63-69.

Hennessy, S., Rolfe, L. \& Chedzoy, S. (2001).The Factors which influence student teachers' confidence to teach the arts in the primary classroom. Research in Dance Education 2(1), 53-71.

Hord, S. M., Rutherford, W. L., Hurling-Austin, L., \& Hall, G. E. (1998). Taking charge of change. Austin, TX: South-west Educational Development Laboratory.

Kane, J. P. (2008). Interplay: Factors affecting the music teaching self-efficacy of pre-service student teachers. Unpublished doctoral dissertation, University of New South Wales. 
Krippendorff, K. (2004). Content analysis: An introduction to its methodology, 2nd ed. Beverly Hills, CA: Sage.

Muijs, D., \& Reynolds, D. (2001). Teachers' beliefs and behaviours: What really matters. Journal of Classroom Interaction, 37, 3-15.

Pascoe, R., Leong, S., MacCallum, J., Mackinlay, E., Marsh, K., Smith, B., et al. (2005). National review of school music education: Augmenting the diminished. Retrieved September 272007 from www.dest.gov.au/sectors/school_education/publications_resourcces/profiles/school_music_education.htm.

Russell-Bowie, D. (2004). Arts education: Are the problems the same across five countries? Paper presented at the Australian Association for Research in Education, 2004, Melbourne.

Temmerman, N. (1997). An investigation of undergraduate music education curriculum content in primary teacher education programmes in Australia. International Journal of Music Education, 30, 26-34.

Tosun, T. (2000). The beliefs of pre-service elementary teachers toward science and science teaching. School Science and Mathematics, 100, 374-379.

Upitis, R., \& Smithrim, K. (2003). Learning through the arts: National assessment 1999-2002. Final report to the Royal Conservatory of Music. Toronto, ON: Royal Conservatory of Music.

\section{About the Author}

Susanne Garvis

The main focus of my work at the University of Queensland has been the professional development of pre-service teachers. My research and teaching interests include teacher education and arts education, with a particular interest in music. I am currently undertaking a $\mathrm{PhD}$ study into the development of beginning teacher self-efficacy beliefs in arts and music education. 



\section{EDITORS}

Mary Kalantzis, University of Illinois, Urbana-Champaign, USA.

Bill Cope, University of Illinois, Urbana-Champaign, USA.

\section{EDITORIAL ADVISORY BOARD}

Michael Apple, University of Wisconsin, Madison, USA.

David Barton, Lancaster University, Milton Keynes, UK.

Mario Bello, University of Science, Cuba.

Manuela du Bois-Reymond, Universiteit Leiden, Leiden, The Netherlands.

Robert Devillar, Kennesaw State University, Kennesaw, USA.

Daniel Madrid Fernandez, University of Granada, Spain.

Ruth Finnegan, Open University, Milton Keynes, UK.

James Paul Gee, University of Wisconsin, Madison, USA.

Juana M. Sancho Gil, University of Barcelona, Barcelona, Spain.

Kris Gutierrez, University of California, Los Angeles, USA.

Anne Hickling-Hudson, Queensland University of Technology, Kelvin Grove, Australia.

Roz Ivanic, Lancaster University, Lancaster, UK.

Paul James, RMIT University, Melbourne, Australia.

Carey Jewitt, Institute of Education, University of London, London, UK.

Andeas Kazamias, University of Wisconsin, Madison, USA.

Peter Kell, University of Wollongong, Wollongong, Australia.

Michele Knobel, Montclair State University, Montclair, USA.

Gunther Kress, Institute of Education, University of London, London, UK.

Colin Lankshear, James Cook University, Cairns, Australia.

Kimberly Lawless, University of Illinois, Chicago, USA.

Sarah Michaels, Clark University, Worcester, USA.

Jeffrey Mok, Miyazaki International College, Miyazaki, Japan.

Denise Newfield, University of Witwatersrand, Johannesburg, South Africa.

Ernest O'Neil, Ministry of Education, Addis Ababa, Ethiopia.

José-Luis Ortega, University of Granada, Granada, Spain.

Francisco Fernandez Palomares, University of Granada, Granada, Spain.

Ambigapathy Pandian, Universiti Sains Malaysia, Penang, Malaysia.

Miguel A. Pereyra, University of Granada, Granada, Spain.

Scott Poynting, Manchester Metropolitan University, Manchester, UK.

Angela Samuels, Montego Bay Community College, Montego Bay, Jamaica.

Michel Singh, University of Western Sydney, Sydney, Australia.

Helen Smith, RMIT University, Melbourne, Australia.

Richard Sohmer, Clark University, Worcester, USA.

Brian Street, University of London, London, UK.

Giorgos Tsiakalos, Aristotle University of Thessaloniki, Thessaloniki, Greece.

Salim Vally, University of Witwatersrand, Johannesburg, South Africa

Gella Varnava-Skoura, National and Kapodistrian University of Athens, Greece.

Cecile Walden, Sam Sharpe Teachers College, Montego Bay, Jamaica.

Nicola Yelland, Victoria University, Melbourne, Australia.

Wang Yingjie, Beijing Normal University, Beijing, China.

Zhou Zuoyu, Beijing Normal University, Beijing, China.

Please visit the Journal website at http://www.Learning-Journal.com for further information about the Journal or to subscribe. 


\section{THE UNIVERSITY PRESS JOURNALS}

\section{The International
JOURNAL Of the ARTS IN SOCIETY}

Creates a space for dialogue on innovative theories and practices in the arts, and their inter-relationships with society.

ISSN: 1833-1866

http://www.Arts-Journal.com

\section{DESIGN PRINCIPLES \& PRACTICES}

Q:

Examines the meaning and purpose of 'design' while also speaking in grounded ways about the task of design and the use of designed artefacts and processes.

ISSN: 1833-1874

http://www.Design-Journal.com

\section{THE GLOBAL STUDIES JOURNAL}

Maps and interprets new trends and patterns in globalisation.

ISSN 1835-4432

http://www.GlobalStudiesJournal.com

\section{The Intermational OU LEARNING}

Sets out to foster inquiry, invite dialogue and build a body of knowledge on the nature and future of learning.

ISSN: $1447-9540$

http://www.Learning-Journal.com

\section{The International $f_{\text {the }}$ INCLUSIVE MUSEUM}

Addresses the key question: How can the institution of the museum become more inclusive? ISSN 1835-2014

http://www.Museum-Journal.com

\section{The Intemational
JOURNAL Of ENVRONMENTAL CUIUURAL}

Draws from the various fields and perspectives through which we can address fundamental questions of sustainability.

ISSN: 1832-2077

http://www.Sustainability-Journal.com

\section{UBIQUITOUS LEARNING}

An International Joum

Investigates the affordances for learning in the digital media, in school and throughout everyday life.

ISSN 1835-2030

http://www.ULJournal.com

\section{The Ineremational $f_{i \text { ibe }}$ BOOK}

Explores the past, present and future of books, publishing, libraries, information, literacy and learning in the information society. ISSN: 1447-9567

http://www.Book-Journal.com

\section{The International
JOURNAL of DIVERSITY in ORGANISATIONS.
COMMUNIIIS \& NATIONS}

Provides a forum for discussion and builds a body of knowledge on the forms and dynamics of difference

and diversity.

ISSN: 1447-9583

http://www.Diversity-Journal.com

\section{JoURNAL Of in HUMANITIES}

Discusses the role of the humanities in contemplating the future and the human, in an era otherwise dominated by scientific, technical and economic rationalisms.

ISSN: 1447-9559

http://www.Humanities-Journal.com

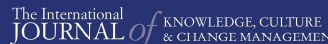

Creates a space for discussion of the nature and future of organisations, in all their forms and manifestations.

ISSN: 1447-9575

http://www.Management-Journal.com

\section{The International}

Discusses disciplinary and interdisciplinary approaches to knowledge creation within and across the various social sciences and between the social, natural and applied sciences. ISSN: 1833-1882

http://www.Socialsciences-Journal.com

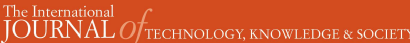

Focuses on a range of critically important themes in the various fields that address the complex and subtle relationships between technology, knowledge and society.

ISSN: $1832-3669$

http://www.Technology-Journal.com

\section{JOURNAL $O f_{\text {the }}$ World Universities Forum}

Explores the meaning and purpose of the academy in times of striking social transformation.

ISSN 1835-2030

http://www.Universities-Journal.com 